\title{
Development of radioimmunoassay and enzyme immunoassays for luteinizing hormone in dromedaries (Camelus dromedarius)
}

\author{
A. Anouassi* and Y. Combarnous \\ Institut National de la Recherche Agronomique, Station de Physiologie de la Reproduction, \\ URA CNRS No 1291, Centre de Recherches de Tours, 37380 Nouzilly, France
}

\begin{abstract}
Summary. Polyclonal antibodies against luteinizing hormone in dromedary (camLH) were raised in a rabbit and enabled the development of homologous immunoassays (radioimmunoassay, competitive enzymeimmunoassay (EIA) and sandwich EIA) for the measurement of circulating camLH in plasma. These assays were highly specific for camLH since neither dromedary follicle-stimulating hormone, growth hormone nor prolactin cross-reacted significantly. The lowest detection limit $(0.08 \mathrm{ng} / \mathrm{ml})$ was obtained with the sandwich EIA. In addition to its high specificity and sensitivity, this method does not require radiolabelled molecules or expensive laboratory facilities. It can be performed in the field using a portable, battery-powered plate reader.
\end{abstract}

Keywords: radioimmunoassay; enzymeimmunoassay; luteinizing hormone; dromedary

\section{Introduction}

The development of immunoassays for the determination of gonadotrophins in the peripheral circulation of the dromedary (Camelus dromedarius) is essential for understanding its reproductive endocrinology and for the development of new techniques to improve its reproductive performance. Dromedaries, which are of great economic importance in desert areas in Africa, have a low rate of reproduction. We aimed to develop assays for camel plasma gonadotrophins that can be easily handled in areas where it is difficult to obtain radioactive elements and where equipment such as centrifuges and radioactivity counters is not available.

Moreover, because of the scarcity of highly purified camLH at the time we initiated this work, we could only immunize a single rabbit. The present paper reports the setting up and characterization of several immunoassays of this hormone with the antiserum obtained, including a highly sensitive and specific sandwich enzymeimmunoassay (EIA).

\section{Materials and Methods}

Hormones. Camel luteinizing hormone (camLH A46; $0.72 \times$ NIH LH S1) was purified as described by Anouassi et al. (1987). Porcine LH (pLH CY1352; $2.4 \times$ NIH LH S1), ovine follicle-stimulating hormone (oFSH CY1746; $50.9 \times$ oFSH NIH S1) and ovine LH isoforms (oLH CY1083, CY1085, CY1086; 2.2-3.5 $\times$ oLH NIH S1) were purified in our laboratory. The methods for the purification of camel prolactin (camPRL NM1140) and camel growth hormone (camGH CY 1712) are described by Martinat et al. (1990a, b). The analogue of gonadotrophin-releasing hormone (Cystorelin) used in this study was from Receptal, France.

Preparation of anti-camLH serum. We first immunized a rabbit with oLH and then reimmunized the same animal with camLH. The oLH used for the initial immunization was a reconstituted mixture of isolated oLH isoforms

*Present address: Department of Animal Reproduction and Artificial Insemination, Institut Agronomique et Vétérinaire, Rabat, Morocco. 
(sp. act. 2.5-3.5 $\times$ NIH LH S1 in rat radioreceptor assay) dissolved in saline and emulsified with complete Freund's adjuvant. One year later, the same rabbit was reimmunized with highly purified camLH (A46) by 6 multiple intradermal injections of $200 \mu \mathrm{g}$ each at intervals of 10 days. Twelve days after the last injection, $30 \mathrm{ml}$ of blood was recovered by incision and gentle vacuum suction of an ear. The antiserum was prepared and kept frozen in 3-ml aliquots at $-20^{\circ} \mathrm{C}$.

Preparation of immunoglobulin $G$ enzyme conjugate. Anti-camLH IgGs were purified from the anti-LH serum by ion-exchange chromatography on DEAE-Trisacryl (IBF, France) as described by the manufacturer. The IgG concentration in the eluate was estimated from its optical density at $280 \mathrm{~nm}(\mathrm{I} \mathrm{mg} / \mathrm{ml}=1.4 \mathrm{D})$. The eluate containing the anti-camLH IgGs was then diluted $\mathrm{v} / \mathrm{v}$ with glycerol and kept at $-20^{\circ} \mathrm{C}$ until use, either for coating of microtitre wells or for conjugation with enzyme. The conjugation of $8 \mathrm{mg} \mathrm{IgG} \mathrm{with} 10 \mathrm{mg}$ horseradish peroxidase (Type VI Sigma; St Louis, USA) was performed in $1 \mathrm{ml}$ of $100 \mathrm{~mm}$ phospate buffer, pH 6.8, with $50 \mu \mathrm{l} 1 \%$ glutaraldehyde. After $3 \mathrm{~h}$ at room temperature in the dark, the reaction was stopped with $50 \mu \mathrm{l} \mathrm{M}$ lysine at $\mathrm{pH} 7 \cdot 4$. After centrifugation at $2000 \mathrm{~g}$ for $20 \mathrm{~min}$ the insoluble material was discarded and the supernatant was diluted $\mathrm{v} / \mathrm{v}$ with glycerol and stored at $-20^{\circ} \mathrm{C}$.

Radioimmunoassay. The radioimmunoassay (RIA) technique was developed using the anti-camLH serum already described. Highly purified camLH (camLH A46) was radiolabelled with ${ }^{125}$ I using iodogen (Pierce) as the catalyst (Fraker \& Speck, 1978); $100 \mu$ l of standard camLH or unknown sample, diluted in 25 mm veronal human serum albumin at $\mathrm{pH} 8.6$, was incubated for 2 days at $4^{\circ} \mathrm{C}$ with $50 \mu \mathrm{l}$ of anti-camLH serum diluted 1:80 000 in the same buffer. Then, $50 \mu \mathrm{l}$ of ${ }^{125} \mathrm{I}$-labelled camLH $(20000$ c.p.m) was added and the incubation was continued for $24 \mathrm{~h}$ at $4^{\circ} \mathrm{C}$. Then, $50 \mu \mathrm{l}$ of a sheep antirabbit $\gamma$-globulin serum was added followed by $50 \mu \mathrm{l}$ of $0.54 \mathrm{M}-\mathrm{CaCl}$ and the tubes were incubated for $30 \mathrm{~min}$ at room temperature to precipitate the anti-camLH antibody. The separation of free and bound hormone was achieved by centrifugation at $2600 \mathrm{~g}$ for $20 \mathrm{~min}$ after addition of $1 \mathrm{ml}$ of cold veronal buffer. The supernatants were discarded and the radioactivity of the pellets (B) was measured in an LKB multigamma counter. The calculations were made by sigmoidal nonlinear regression on the values of $(\mathrm{B} / \mathrm{Bo})$ as a function of the log of hormone concentrations using the GraphPAD 2.0 program (ISI Software). The whole procedure was completed in 3 days.

Competitive enzymeimmunoassay. The wells of microtitre plates (CML, Angers, France) were coated with $100 \mathrm{ng}$ of highly purified porcine LH (pLH CY 1352; $2.4 \times \mathrm{NIH} \mathrm{LH} \mathrm{SI)} \mathrm{in} 100 \mu$ l of $100 \mathrm{~mm}$ carbonate-bicarbonate, pH 9.6 (at $37^{\circ} \mathrm{C}$ for $1 \mathrm{~h}$ ). Before use, the plates were emptied by inversion, dried on absorbent paper and the wells were saturated with proteins by incubating $150 \mu \mathrm{l}$ phosphate-buffered saline (PBS) containing 2 mg bovine serum albumin (BSA; Sigma) $/ \mathrm{ml}$ and $0.1 \%$ Tween in each of them for $30-60 \mathrm{~min}$ at $37^{\circ} \mathrm{C}$. Serial dilutions of the standards and unknowns were performed in polystyrene tubes with phosphate-buffered saline (PBS), bovine serum albumin (BSA) and Tween. Then, $200 \mu$ l of the anti-camLH antibody (1:10000 dilution in the same buffer) was added to $200 \mu l$ of each dilution. After incubation for $3 \mathrm{~h}$ at $37^{\circ} \mathrm{C}$, three $100 \mu \mathrm{l}$ aliquots were transferred to triplicate wells coated with $\mathrm{pLH}$ and incubated for $1 \mathrm{~h}$ at $37^{\circ} \mathrm{C}$. The wells were then emptied by inversion dried on filter paper and washed 5 times with PBS and Tween. Subsequently, bound anti-camLH antibodies were detected by incubation for $1 \mathrm{~h}$ with antirabbit $\gamma$-globulin antibody conjugated to peroxidase (Pasteur Production, France). The wells were then washed 5 times with PBS and Tween buffer and the bound enzyme activity was assayed by addition of $100 \mu$ l substrate solution $\left(0.5 \mathrm{mg} \mathrm{O}\right.$-phenylenediamine $/ \mathrm{ml}$ and $0.2 \% \mathrm{H}_{2} \mathrm{O}_{2}$ in $0.1 \mathrm{M}$ citrate, $\left.\mathrm{pH} 5.6\right)$ and incubation at room temperature in the dark for 5-10 min. The reaction was stopped by $50 \mu \mathrm{H} \mathrm{H}_{2} \mathrm{SO}_{4}$ and the optical density $(D)$ at $492 \mathrm{~nm}$ was measured on a Dynatec plate reader; $D$ was plotted as a function of the log of hormone concentrations and the curves obtained were analysed by sigmoidal curve fitting using the GraphPAD program.

Avidin-biotin competitive enzymeimmunoassay. This technique is a modification of the previous one: the wells of microtitre plates were coated with $10 \mathrm{ng}$ of highly purified porcine $\mathrm{LH}$, instead of $100 \mathrm{ng}$. The anti-camLH serum was used at a dilution of 1:80000 instead of 1:10000; biotinylated antirabbit $\gamma$-globulin antibody (Pasteur Production, France) was used instead of antirabbit $\gamma$-globulin antibody conjugated to peroxidase and an additional incubation for $1 \mathrm{~h}$ at $37^{\circ} \mathrm{C}$ with avidin conjugated to peroxidase was performed. After 5 washings, the bound enzyme was determined and the calculations were made in the same way as for the standard competitive EIA.

Sandwich enzymeimmunoassay. In this assay, the IgGs purified from the above anti-camLH serum were used both as capture and detection antibodies, as described for bovine LH by Abdul-Ahad \& Gosling (1987). The wells of EIA microtitre plates were coated with $0.4 \mu \mathrm{g}$ anti-camLH IgGs diluted in $100 \mu \mathrm{l}$ of $100 \mathrm{~mm}$ carbonate-bicarbonate, $\mathrm{pH} 9.6$, by incubation at $37^{\circ} \mathrm{C}$ for $1 \mathrm{~h}$ and subsequent storing at $4^{\circ} \mathrm{C}$ for $0.5-15.0$ days. They were emptied and rinsed just before use. Standard LH or unknowns were diluted in PBS, BSA and Tween and 100- $\mu$ l samples were added to the wells. The plates were then incubated either for $1 \mathrm{~h}$ at $37^{\circ} \mathrm{C}$ or overnight at $4^{\circ} \mathrm{C}$. The wells were emptied and washed 3 times with $150 \mu \mathrm{l}$ PBS-Tween, then $100 \mu \mathrm{l}$ of anti-camLH-peroxidase conjugate diluted 1:2000 (corresponding to $\sim 0.2 \mu \mathrm{g}$ anti-LH IgG) was added and incubated for $3 \mathrm{~h}$ at $37^{\circ} \mathrm{C}$. After 5 washings, the bound enzyme activity was determined. The linear regression analysis of $\log (D)$ as a function of $\log ($ dose) was performed with the GraphPAD program.

Biological samples. Adult female dromedaries $(400-500 \mathrm{~kg})$ were studied during the breeding season and had previously calved at least once. They were isolated from the male for 4 months before the experiments; $10 \mathrm{ml}$ of blood was collected from the jugular vein every $30 \mathrm{~min}$ for $5 \mathrm{~h}$ in sodium citrate. Plasma samples were prepared by centrifugation at $2600 \mathrm{~g}$ at $4^{\circ} \mathrm{C}$ and kept frozen until assay. These samples were obtained from female animals either treated 
by a single intravenous injection of $50 \mu \mathrm{g} \mathrm{GnRH}$ or submitted to $2-\mathrm{h}$ inhalation of occipital gland secretions. These secretions were recovered from sexually mature males on cotton pads that were placed inside plastic masks positioned over the nostrils of females.

\section{Results}

\section{Radioimmunoassay}

The Hill slopes of the calculated sigmoid curves of the homologous RIA of camLH were -0.93 $( \pm 0.07)$ and $-1.07( \pm 0.16)$ for purified camLH and a sample of dromedary plasma, respectively (Fig. 1a). The detection limit of this assay, as calculated from the error in the zero was $0.2 \mathrm{ng} / \mathrm{ml}$ (20 pg/tube) and the cross-reactivity of camFSH was $<2 \%$.

\section{Competitive enzymeimmunoassay}

CamFSH and camPRL did not cross-react significantly in this assay (Fig. Ib). The sensitivity calculated from multireplicate analysis of hormone-free standard was $10 \mathrm{ng} \mathrm{camLH} / \mathrm{ml}$ of sample. By amplification of the response with the avidin-biotin system (see Materials and Methods), the detection limit was lowered to $1.6 \mathrm{ng} / \mathrm{ml}$ (not shown).

\section{Sandwich enzymeimmunoassay}

The detection limit for camLH in the short protocol (incubation for $1 \mathrm{~h}$ at $37^{\circ} \mathrm{C}$ ) was $0.6 \mathrm{ng} / \mathrm{ml}$ (Fig. 2a). The detection limit for oLH was four times lower $(0 \cdot 16 \mathrm{mg} / \mathrm{ml})$. The cross-reactions with camFSH, oFSH, camGH and camPRL were very low. Indeed, camFSH was $<0 \cdot 1 \%$ as active as camLH, and oFSH exhibited $<1 \%$ of the activity of oLH. camGH and camPRL exhibited very low activities $(<0 \cdot 1 \%)$.

In the sandwich assay of camLH in the long protocol (overnight incubation at $4^{\circ} \mathrm{C}$ ), the detection limit for camLH, statistically defined as the zero point plus twice the standard deviation,

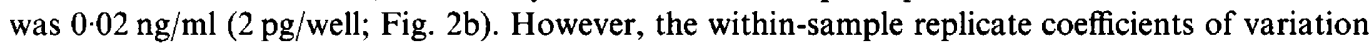
were $>7 \%$ for camLH concentrations $<0.08 \mathrm{ng} / \mathrm{ml}$. Therefore, the range of the assay with high precision is $80 \mathrm{pg}$ to $10 \mathrm{ng} / \mathrm{ml}$ sample (i.e. $8-1000 \mathrm{pg} /$ well). The within-assay variation never exceeded $3.2 \%$ (Fig. 3) whereas the between-assay coefficient of variation for a control plasma sample $(6 \cdot 6 \mathrm{ng} / \mathrm{ml})$ was $7 \cdot 8 \%(n=6)$.
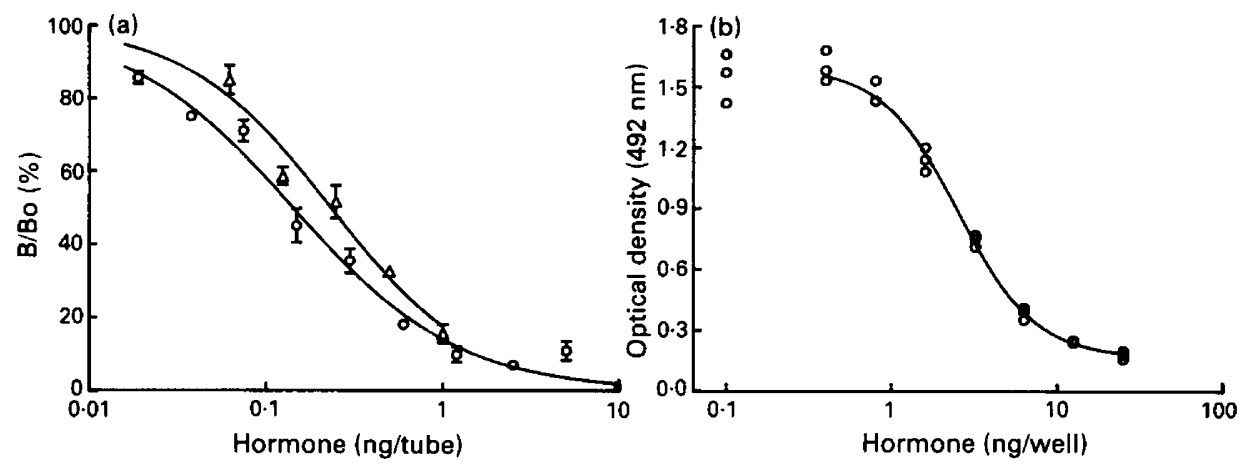

Fig. 1. Assays of dromedary luteinizing hormone (camLH): (a) Homologous radioimmunoassay for highly purified camLH at 1:10 dilution $(O)$ data and for a dromedary plasma at 1:1 dilution $(\triangle)$. B:Bo is ratio of bound:unbound radioactive tracer. Each dose was performed in triplicate. (b) Competitive enzymeimmunoassay. Each point was performed in triplicate. Data were analysed by nonlinear sigmoid regression. 

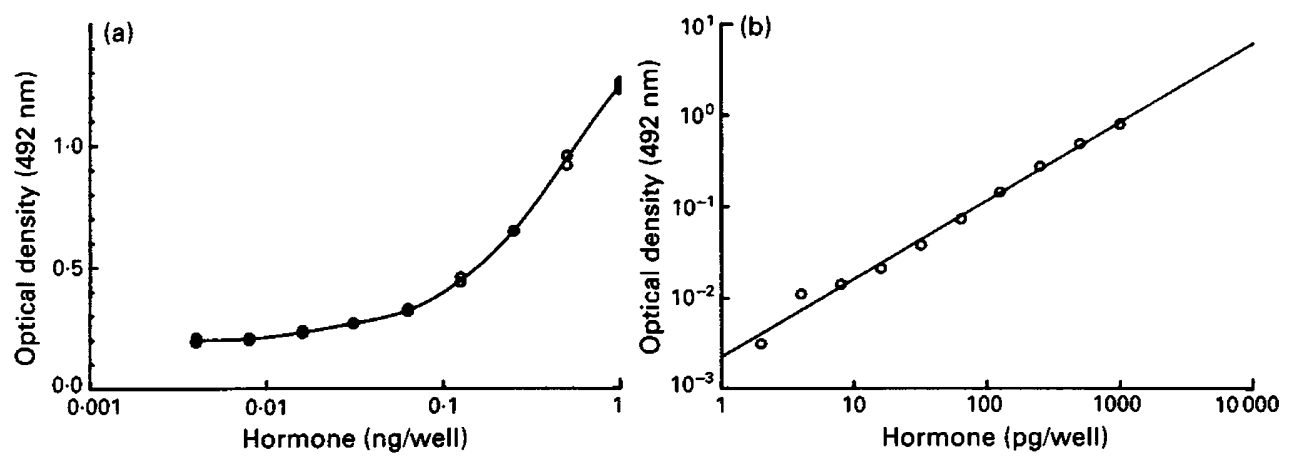

Fig. 2. Standard curves of sandwich enzymeimmunoassays of dromedary luteinizing hormone (camLH). (a) Short protocol, incubated for $1 \mathrm{~h}$ at $37^{\circ} \mathrm{C}$ in triplicate. Data were analysed by nonlinear sigmoid regression. (b) Long protocol. Data are means of 7 replicates incubated overnight at $4^{\circ} \mathrm{C}$. Data were analysed by linear regression and s.e.m. are smaller than the symbols.

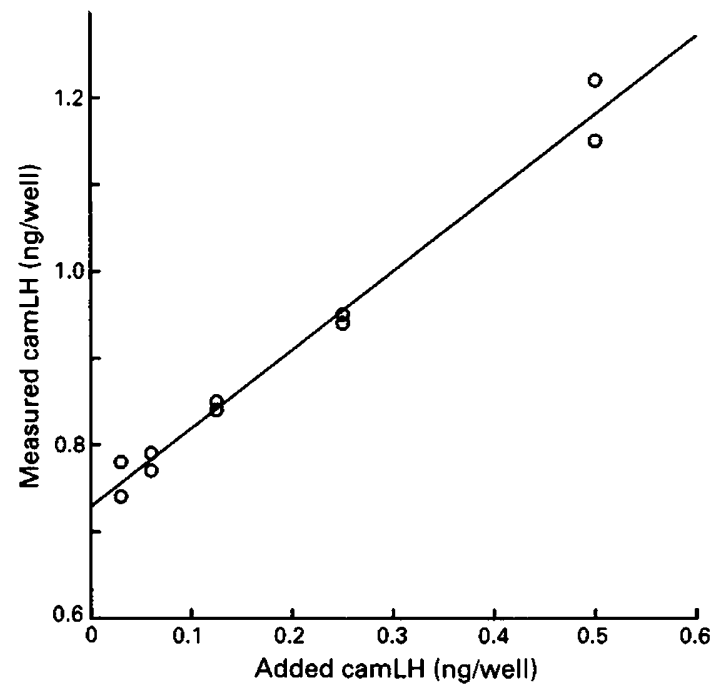

Fig. 3. Recovery of dromedary luteinizing hormone (camLH) added to plasma sample in the sandwich enzymeimmunoassays (long protocol). Data were analysed by linear regression. Slope $=0.906, y$ intercept $=0.728 \mathrm{ng} /$ well, $r^{2}=0.984$.

\section{Clinical validation of the sandwich EIA}

Injection of $\mathbf{G n R H}$. Blood samples were taken from normal female dromedaries before and after i.v. injection of $50 \mu \mathrm{g} \mathrm{GnRH}$. Plasma LH concentrations, measured by the long protocol sandwich EIA, increased after GnRH treatment (Fig. 4a).

Male effect. Plasma LH concentration increased when male occipital secretions were smelled by female dromedaries (Fig. 4b).

\section{Discussion}

We (Marie \& Anouassi, 1986) and others (Xu et al., 1985; Elwishy, 1987; Bono et al., 1989) have used different heterologous immunoassays to follow circulating LH profiles in dromedaries or 


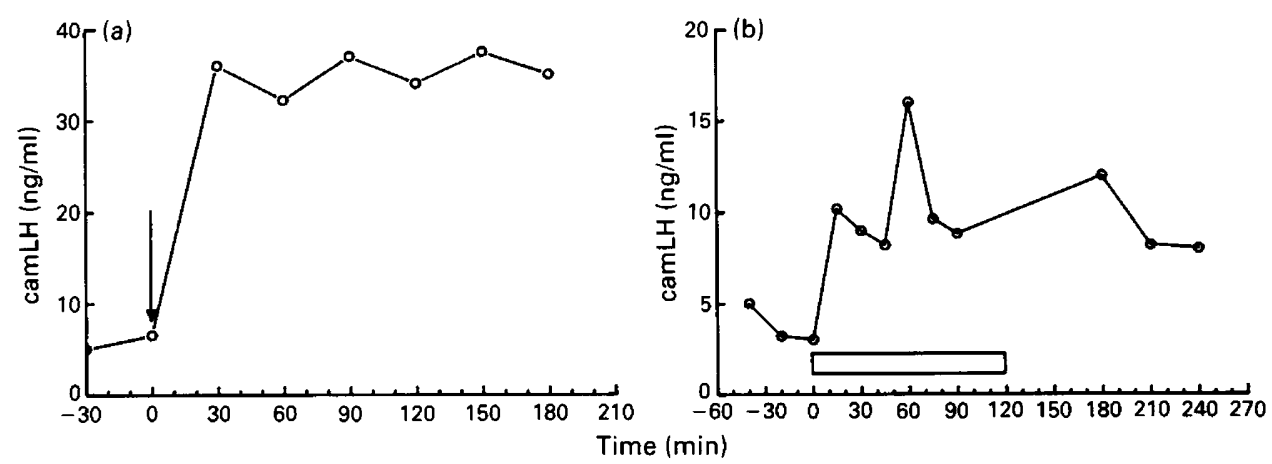

Fig. 4. Analysis of plasma samples. Measurement of luteinizing hormone by the sandwich enzymeimmunoassays (long protocol) in female dromedaries (a) injected with $50 \mu \mathrm{g}$ gonadotrophin-releasing hormone $(\mathrm{GnRH})$ at the time indicated by the arrow or (b) submitted to male occipital odour ( $\square$ ).

bactrian camels, but the lack of highly purified camLH standard preparations precluded the determination of the absolute values of $\mathrm{LH}$ concentrations. This paper is the first report of homologous immunoassays (RIA and EIA) for camLH.

The purification method of camLH previously described (Anouassi et al., 1987) allowed us to raise specific antibodies in a rabbit. However, because of the limited amount of camLH available, we obtained the antiserum by the administration of boosting injections of camLH to a rabbit previously immunized against ovine LH.

The anti-camLH serum obtained enabled us to set up a specific RIA with good sensitivity $(0.2 \mathrm{ng} / \mathrm{ml})$. Despite this high sensitivity, we did not further validate this RIA because it necessitates regular radioiodinations of hormone and, consequently, a continuous supply of radioisotopes. Moreover, the assay must be performed in a laboratory with a refrigerated centrifuge and radioactivity counter. Since dromedaries are bred in areas with no or few laboratory facilities, we chose to develop hormone assays that can be performed with cheap equipment and reagents having a long shelf-life at $4^{\circ} \mathrm{C}$.

We first set up a competitive EIA because, in this technique, the microtitre wells are coated with the antigen, which is generally much more readily available than the antibody. Nevertheless, because camLH is scarce, we used LH from another species. Since the polypeptide structure of porcine LH is similar to that of camel LH (Combarnous et al., 1989) and since purified pLH is available in large amounts, we chose this hormone. Although the resulting assay was very specific, its detection limit was far too high $(10 \mathrm{ng} / \mathrm{ml})$ for the measurement of the hormone in the circulation, but, because of its rapidity and convenience, it is suitable for monitoring LH immunoactivity during purifications. The use of avidin-biotin for amplification led to a lower detection limit $(1.6 \mathrm{ng} / \mathrm{ml}$, i.e. $160 \mathrm{pg} /$ well $)$, but it was still too high for measuring the expected basal concentrations of $\mathrm{LH}$.

To set up an enzymeimmunoassay of sufficient sensitivity, we then turned to a sandwich EIA using a single polyclonal antiserum as previously described for bovine LH (Abdul-Ahad \& Gosling, 1987). This assay was found to be highly specific for $\mathrm{LH}$ molecules. The rapid protocol $\left(37^{\circ} \mathrm{C}\right.$ for $1 \mathrm{~h})$ gave a detection limit of $1 \mathrm{ng} / \mathrm{ml}$ for camLH and this limit was even lower for ovine $\mathrm{LH}$ $(0.25 \mathrm{ng} / \mathrm{ml}$, i.e. $25 \mathrm{pg} /$ well $)$. This is not unexpected since the rabbit was first immunized with oLH and subsequently boosted with camLH.

Since basal circulating concentrations of $\mathrm{LH}$ in dromedaries are probably $<1 \mathrm{ng} / \mathrm{ml}$, we modified the protocol to reach a suitable detection limit. This was obtained by incubating the standards or samples with the coated antibodies overnight at $4^{\circ} \mathrm{C}$ instead of for $1 \mathrm{~h}$ at $37^{\circ} \mathrm{C}$. In this assay, the detection limit was as low as $20 \mathrm{pg} / \mathrm{ml}$, but the $\mathrm{CV}$ was $>10 \%$ at this hormone concentration. The 
range of the assay with high precision (CV $<7 \%$ ) for camLH was then $80-1000 \mathrm{pg} / \mathrm{ml}(8-100 \mathrm{pg} /$ well) and was satisfactory for the measurement of basal and peak concentrations of the hormone in the circulation.

We previously reported that camLH could be measured by RIAs for ovine LH (Marie \& Anouassi, 1986) or RIAs for porcine LH or equine choriogonadotrophin (Anouassi et al., 1987). Recently, a sandwich EIA for oLH was set up in our laboratory (by M. C. Maurel) using anti-oLH serum from rabbit that was subsequently boosted with camLH. In this assay, camLH cross-reacted strongly $(50 \%$ of oLH) with a detection limit of $0.1 \mathrm{ng} / \mathrm{ml}$. The boosting injections of camLH performed 1 year after immunization against oLH were intended to activate selectively clones secreting antibodies to specific epitopes of camLH. The resulting antiserum exhibited the same specificity towards oLH and camLH and the detection limit in the long-protocol, homologous, sandwich EIA was slightly lowered.

Although different heterologous LH immunoassays (RIA or EIA) can be used for the measurement of camLH, the homologous EIAs described here have the advantages that real concentrations are measured and that they can be performed in the field with cheap portable equipment. The preliminary biological data presented in this report demonstrate the feasibility of the camLH sandwich EIA.

We are indebted to M. Hamani, N. Martinat and F. Lecompte for their help. Thanks are also due to Dr Raiti for providing us with NIH standards. This study was supported in part by the Centre National de la Recherche Scientifique (CNRS), by the French Ministry of Foreign Affairs and the Fondation pour la Recherche en Hormonologie (FRH).

\section{References}

Abdul-Ahad, W.G. \& Gosling, J.P. (1987) An enzymelinked immunosorbent assay (ELISA) for bovine LH capable of monitoring fluctuations in baseline concentrations. J. Reprod. Fert. 80, 653-661.

Anouassi, A., Combarnous, Y., Lecompte, F., Cahoreau, C., Guillou, F. (1987) Purification and characterization of luteinizing hormone from the dromedary (Camelus dromedarius). Biochimie 69, 647-654.

Bono, G., Moallim Dahir, A., Comin, A. \& Ahmed Jumale, M. (1989) Plasma LH, corticoid and sex steroid variations in camels (Camelus dromedarius) in relation to seasonal climatic changes. Anim. Reprod. Sci. 21, 101-113.

Combarnous, Y., Huet, J.C., Martinat, N., Mansion, M., Anouassi, A. \& Pernollet, J.C. (1989) $N$-terminal amino-sequencing of camel (Camelus dromedarius) luteinizing-hormone $\alpha$ and $\beta$ subunits. Pathol. Biol. 37, 814-818.

Elwishy, A.B. (1987) Reproduction in the female dromedary (Camelus dromedarius): a review. Anim. Reprod. Sci. 15, 273-297.

Fraker, P.J. \& Speck, J.C. (1978) Protein and cell membrane iodinations with sparingly soluble chloramide 1,3,4,6-tetrachloro-3,6-diphenylglycouril. Biochem. Biophys. Res. Commun. 80, 632-638.

Marie, M. \& Anouassi, A. (1986) Mating-induced luteinizing hormone surge and ovulation in the female camel (Camelus dromedarius). Biol. Reprod. 35, 792798.

Martinat, N., Anouassi, A., Huet, J.C., Pernollet, J.C. \& Combarnous, Y. (1990a) Purification and characterization of glycosylated and non-glycosylated forms of prolactin from the dromedary (Camelus dromedarius). Comp. Biochem. Physiol. 97, 667-674.

Martinat, N., Anouassi, A., Huet, J.C., Pernollet, J.C., Segard, V. \& Combarnous, Y. (1990b) Purification and partial characterization of growth hormone from the dromedary (Camelus dromedarius). Domestic Anim. Endocr. 7, 527-536.

Xu, Y.S., Wang, H.Y., Zeng, G.Q., Jiang, G.T. \& Gao, Y.H. (1985) Hormone concentrations before and after semen-induced ovulation in the bactrian camel (Camelus bactrianus). J. Reprod. Fert. 74, 341-346.

Received 8 October 1990 